Dept. of Animal Medicine, Infectious Diseases,

Fac. of Vet. Med., Assiut University, Assiut 71526, Egypt.

\title{
EPIZOOTIOLOGICAL STUDIES ON TICK INFESTATION AMONG DROMEDARY CAMELS IN UPPER EGYPT
}

(With 5 Tables and 3 Figures)

\author{
By \\ MAHA I. HAMED; A.A. ZAITOUN; T.A.A. EL-ALLAWY \\ and M.I. MOURAD \\ (Received at 15/9/2010)
}

دراسات وبائية عن الاصابة بالقراد فى الابل بصعيد مصر

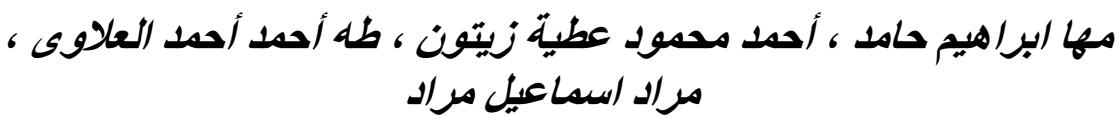

الهدف من هذا العمل هو دراسة العلاقة بين الإصابة بللقر اد في الجمال و الجنس و العمر ومواسم

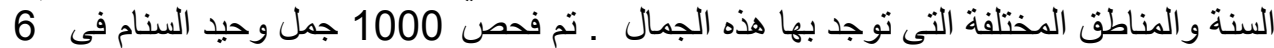

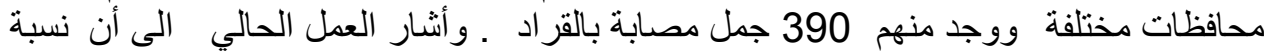

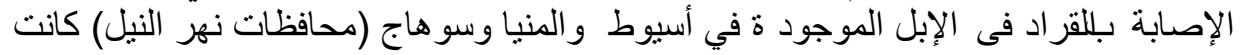

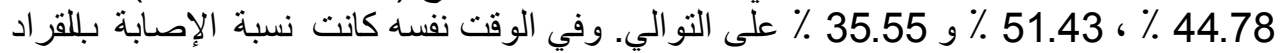

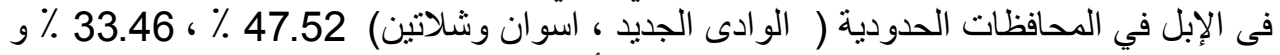

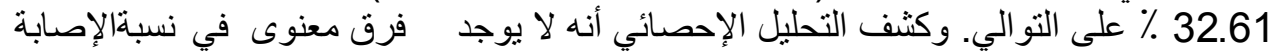

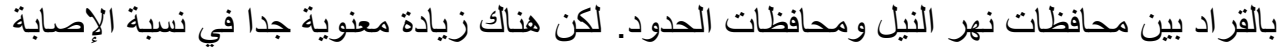

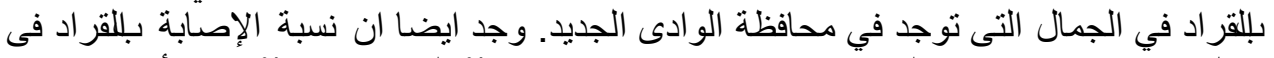

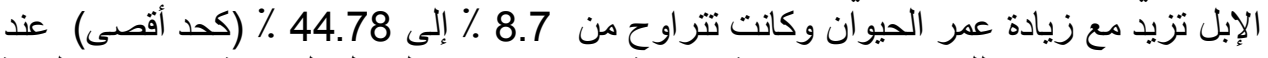

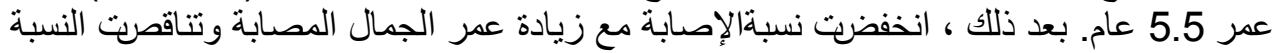

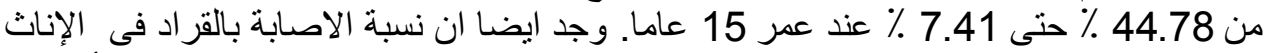

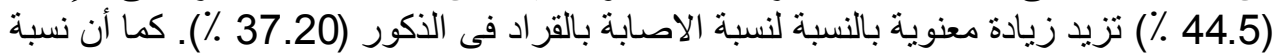

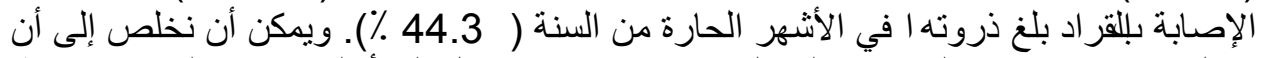

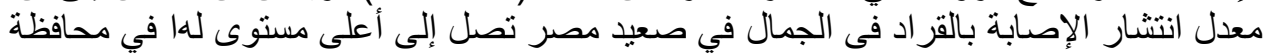
الو ادى الجديد وخصوصا خلال الأشهر الحارة من السنة والجمال التى تبلغ التعل 5.5 عام هي الأكثر 


\section{SUMMARY}

The goal of the present work was to study tick infestation in camels in relation to different localities, age, sex and seasons. A total number of 1000 one humped camels were investigated, out of the investigated camels, three hundred and ninety were infested with ticks. The current work indicated that the prevalence of tick infestation of the examined camels located in Assiut, El-Minia and Sohag (River Nile Governorates) were 44.78\%, $51.43 \%$ and $35.55 \%$ respectively. Meanwhile the prevalence rates of tick infestation of camels in the border governorates (El-Wady El-Gadid, Aswan and Shalatin) were $47.52 \%, 33.46 \%$ and $32.61 \%$ respectively. Statistical analysis revealed that there was no significant variation at $\mathrm{P}<0.05$ between prevalence rates of tick infestation in River Nile Governorates and Border Governorates. There was highly significant increase in prevalence of tick infestation in camels located in El-Wady ElGadid governorate at $\mathrm{P}<0.05$. The prevalence of tick infestation of the examined camels was primarily increased by increasing the age of the animal and the infestation rate ranged from $8.7 \%$ to $44.78 \%$ (maximum) at 5.5 years. Thereafter, the prevalence of tick infestation was decreased by increasing in the age of infested camel and the percent of infection decreased from $44.78 \%$ till $7.41 \%$ at 15 years. The susceptibility rate of females $(44.5 \%)$ to tick infestation was highly significant $(\mathrm{p}<0.01)$ in contrast to males $(37.20 \%)$. The percentage of infestation with ticks reached its peak $(\mathrm{p}<0.01)$ at hot months of the year $(44.3 \%)$. It could be concluded that prevalence of tick infestation in Upper Egypt reach its highest level in El-Wady El-Gadid governorate especially during the hot months of the year and camels 5.5 years of age is the most affected.

\section{Keywords: Epizootiology, camel ticks, tick infestation, Upper Egypt.}

\section{INTRODUCTION}

Ticks are obligate blood suckers of mammals and birds and they appear to be the most serious ectoparasites of animals under Egyptian field conditions particularly in Upper Egypt. Ticks comprise a major problem affecting the health and impairing the profitable productivity of Egyptian camels (El-Kady, 1998 and Hamed, 2005). The overall prevalence of tick infestation in camels in some areas at Egypt were reported by Amin et al. (2006) and it was $48.65 \%$, they also found that Hyalomma dromedarii was the most predominant identified tick species $(81 \%)$. Also El-Badr et al. (2007) studied the ectoparasites of camels in Sohag Governorate and they found that out of 200 slaughtered camels $50(25 \%)$ were infested by ticks. 
Camels may be infested with ticks at any time throughout the year however numbers could fluctuate greatly with climate (Steward, 1950). There was fairly constant age effect apparent in all herds, as adult camels generally carried more ticks than immature which in turn carried more ticks than the neonates. There was also no significant relationship between sex of host and tick load Dolan et al. (1983). Infestation with ticks among dromedary camels in Upper Egypt was studied before by Mahran and Saleh (2004), Hamed (2005) and Amin et al. (2006) and they found that highest percentage of tick infestation was in camels between 9-16 years of age, and it was obviously higher in summer season (hot months) than in cold months. The goal of the present work was to study tick infestation in camels in relation to different localities, age, sex and seasons.

\section{MATERIALS and METHODS}

\section{Animals:}

A total number of 1000 one humped camels were investigated in this study, during the period from July 2007 - January 2009 and their data (age, sex, weight and locality) were recorded.

\section{Prevalence of tick infestation:}

Prevalence of tick infestation among the examined camels was calculated mathematically by conventional methods described by Chatfield (1970).

\section{Ecological distribution:}

The localities were belonged to El Menia, Assiut, Sohage, El Wady El Gadid, Aswan Governorates and Shalatin area- Egypt. Ecologically it were categorized into desert (border Governorates), and cultivated (irrigated) or River Nile Governorates. The River Nile Governorates included El Menia, Assiut, Sohage Governorates and the border Governorates included El Wady El Gadid, Aswan Governorates and Shalatin area (Red Sea Governorate).

Prevalence of tick infestation of the examined camels located in different localities of Upper Egypt was statistically analyzed. Statistical analysis was performed to reveal-up the significant and/or the insignificant effect of the ecology on the prevalence of tick in camel populations using one-way analysis of variance (ANOVA) according to the methods described by Chatfield (1970).

\section{Age susceptibility of the examined camels to tick infestation:}

The examined camels were grouped according to age into 4 major groups based on camelmen: group A included neonates and growing camels $0-3$ years $(n=118)$, group B included mature camels 3-7 years 
$(\mathrm{n}=310)$, group $\mathrm{C}$ included adult camels $8-11$ years $(\mathrm{n}=452)$ and group $\mathrm{D}$ included aged camels more than 11 years of age $(n=120)$. Within each group, the examined camels were classified into categories as shown in Table 1.

The linear relationship between prevalence (\% affected) of tick infestation and ages of the infested camels (average age) was statistically studied using simple linear regression according to the methods illustrated by Chatfield (1970).

To increase the fitness, ages of the examined camels were divided to two stages (sets). The first set was from the 3 months to 5.5 years, and the second stage was from 7.5 years to 18 years. Subsequently the simple regression line equation was divided into two sets ( 1 and 2$)$ according to the ages of the examined camels to increase the value of " $\mathrm{R}$ " (coefficient of determination).

\section{Sex susceptibility:}

Camels were also classified according to their sex into males $(n=755)$ and females $(n=245)$. The susceptibility rates of examined camels to tick infestation were also statistically analyzed using CHI square analysis according to the methods described by Milton and Tsokos (1983).

\section{Seasonal variation:}

The Meteorological station of the Faculty of Agriculture, Assiut University, Assiut, Egypt reveals that the climatic season in Upper Egypt, particularly in Assiut Governorates and in desert areas (El-Wadi-El-Gadid and Shalatin) is generally classified into two periods; hot and non-hot (cold). The hot period usually begin from April to the half of November (seven and half month), whereas the non-hot period occupies the rest of the year (approx. five months), Abruptly changes during each climatic-period may occur but they are seldom. The susceptibility rates of 1000 camels to tick infestation in different climatic season of Upper Egypt were also statistically analyzed using CHI square analysis according to the methods described by Milton and Tsokos (1983).

\section{RESULTS}

\section{Prevalence of tick infestation:}

During the period, July 2007 till January 2009, a total number of 1000 camels of different ages and sex, and in different localities were clinically examined. Out of these camels, 390 camels (39\%) were clinically infested by ticks. 


\section{Spatial distribution:}

The current work indicated that the prevalence of tick infestation in the examined camels located in El-Minia, Assiut and Sohag Governorates were $44.78 \%, 51.43 \%$ and $35.55 \%$ respectively (Table 2). Meanwhile the prevalence rate of tick infestation of camels in the border governorates (El-Wady El-Gadid, Aswan and Shalatin) is $47.52 \%, 33.46 \%$ and $32.61 \%$ respectively.

Table (2) also indicated that the prevalence rate of ticks was mathematically high in camels located in neighborhood the River Nile Governorates (El-Minia, Assiut and Sohage, $\mathrm{n}=268$ camel) than those located in the Border governorates (El-Wady El-Gadid, Aswan and Shalatin, $\mathrm{n}=732$ camel). However the statistical analysis revealed that there was no significant variation at $\mathrm{P}>0.05$.

On the other side, statistical analysis by using $\mathrm{F}$ test analysis of variance (ANOVA) revealed that there was no significant variation in the prevalence of ticks of camels located in El-Minea, Assiut and sohage (River Nile governorates) at $\mathrm{P}<0.05$, in spite of the prevalence rate in ElMinia was $51.43 \%$.

Statistical analysis of the prevalence of ticks among infested camels in border governorates (El-Wady El-Gadid, Aswan and Shalatin) cleared that there was a highly significant increase in the prevalence of tick infestation among camels located in El-Wady El-Gadid governorate at $\mathrm{P}<0.05$.

\section{Age susceptibility:}

The obtained results that illustrated in Table (3) and Figure (1) indicated that the prevalence of tick infestation among the examined camels was primarily increased by increasing the age of the animal and the infestation rate ranged from $8.7 \%$ to $44.78 \%$ (maximum) at 5.5 years. Thereafter, the prevalence of tick infestation was decreased by increasing in the age of infested camel and the percent of infection decreased from $44.78 \%$ till $7.41 \%$ at 15 years. Camels above 18 years were found to be clinically free of ticks. Neonates and young camels with 3-5 months were also found to be with no tick infestation. Statistically the relationship between age of camels and the prevalence rate of tick was studied by simple regression line, which revealed that there was a strong positive correlation (correlation coefficient, $r=0.97$ ) between the prevalence of tick and age of camel till 5.5 years (Figure 2), thereafter the trend line in dramatically decline indicating a strong negative correlation (correlation coefficient, $r=-0.99$ ) (Figure 3 ), begins form 7 years till 18 years. 


\section{Sex susceptibility:}

Regarding to sex susceptibility, the obtained results listed on Table (4) indicated that 281 of $755(37.20 \%)$ clinically examined male camels were infested with ticks, whereas 109 of 245 female animals $(44.5 \%)$ were infested. The statistical analysis by using $\mathrm{F}$ test analysis of variance revealed that there was a highly significant variation $(\mathrm{P}<0.01)$ between female and male infested camels. Females were more susceptible to tick infestation than in males.

\section{5- Seasonal influence:}

Concerning the seasonal influence on the prevalence of ticks of the examined camels, it was found that 288 of 650 (44.3\%) camels were infested with ticks during the hot months (from April till October). Whereas, during the cold months the obtained results indicated that $29.1 \%$ of camels were infested by ticks (Table 5). Statistically, the statistical analysis by using $\mathrm{F}$ test analysis of variance revealed that there was a highly significant increase $(\mathrm{P}<0.01)$ of tick infestation during hot months of the year.

Table 1: Classification of examined camels according to age:

\begin{tabular}{|c|c|c|c|c|}
\hline \multicolumn{2}{|l|}{ Age groups } & $\begin{array}{l}\text { Number of } \\
\text { camels }\end{array}$ & Categories & $\begin{array}{c}\text { Number of } \\
\text { camels }\end{array}$ \\
\hline \multirow{5}{*}{$\begin{array}{l}\text { A-Neonate } \\
\text { and } \\
\text { growing } \\
\text { Camels }\end{array}$} & \multirow{5}{*}{$0-3$ years } & \multirow{5}{*}{118} & 3 months & 10 \\
\hline & & & 6 months & 23 \\
\hline & & & 1 year & 31 \\
\hline & & & 1.5 & 25 \\
\hline & & & 2.5 & 29 \\
\hline \multirow{3}{*}{$\begin{array}{l}\text { B- Mature } \\
\text { Camels }\end{array}$} & \multirow{3}{*}{$3-7$ years } & \multirow{3}{*}{310} & 3.5 & 30 \\
\hline & & & 5.5 & 134 \\
\hline & & & 7.5 & 146 \\
\hline \multirow{3}{*}{$\begin{array}{l}\text { C- } \\
\text { Adult } \\
\text { Camels }\end{array}$} & \multirow{3}{*}{$8-11$ years } & \multirow{3}{*}{452} & 8.5 & 201 \\
\hline & & & 9.5 & 181 \\
\hline & & & 11 & 70 \\
\hline \multirow{3}{*}{$\begin{array}{l}\text { D- } \\
\text { Aged } \\
\text { Camels }\end{array}$} & \multirow{3}{*}{$\begin{array}{c}\text { More than } \\
11 \text { years }\end{array}$} & \multirow{3}{*}{120} & 13 & 82 \\
\hline & & & 15 & 27 \\
\hline & & & 18 & 11 \\
\hline
\end{tabular}


Table 2: Prevalence of tick infestation among the examined camels $(n=1000)$ at different localities of Upper Egypt.

\begin{tabular}{|c|c|c|c|c|}
\hline \multicolumn{2}{|c|}{ Governorate } & \multirow{2}{*}{ 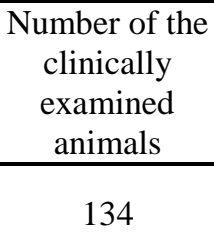 } & \multirow{2}{*}{ 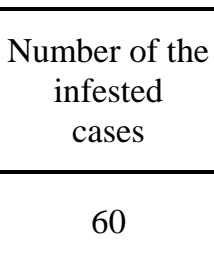 } & \multirow{2}{*}{$\begin{array}{c}\% \text { of } \\
\text { infestation } \\
44.78\end{array}$} \\
\hline \multirow{3}{*}{ 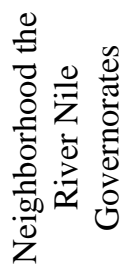 } & Assiut & & & \\
\hline & El-Minea & 35 & 18 & 51.43 \\
\hline & Sohage & 99 & 35 & 35.55 \\
\hline \multicolumn{2}{|c|}{ Total } & 268 & 113 & 42.16 \\
\hline \multirow{3}{*}{ 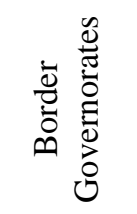 } & $\begin{array}{c}\text { El-Wady El- } \\
\text { Gadid }\end{array}$ & 242 & 115 & 47.52 \\
\hline & Aswan & 260 & 87 & 33.46 \\
\hline & Shalatine & 230 & 75 & 32.61 \\
\hline \multicolumn{2}{|c|}{ Total } & 732 & 277 & 37.84 \\
\hline
\end{tabular}

Table 3: Age susceptibility of examined camels to tick infestation.

\begin{tabular}{|c|c|c|c|}
\hline $\begin{array}{c}\text { Ages/year } \\
\text { (Average) }\end{array}$ & $\begin{array}{c}\text { Number of clinically } \\
\text { inspected } \\
\text { animals }\end{array}$ & $\begin{array}{c}\text { Number of diseased } \\
\text { animals }\end{array}$ & $\begin{array}{c}\text { Percentage } \\
\text { of infestation }\end{array}$ \\
\hline 0.25 & 10 & 0 & 0 \\
\hline 0.5 & 23 & 2 & 8.7 \\
\hline 1 & 31 & 4 & 12.9 \\
\hline 1.5 & 25 & 5 & 20 \\
\hline 2.5 & 29 & 8 & 36.67 \\
\hline 3.5 & 30 & 11 & 44.78 \\
\hline 5.5 & 134 & 60 & 25.34 \\
\hline 7.5 & 146 & 37 & 20.89 \\
\hline 8.5 & 201 & 42 & 19.89 \\
\hline 9.5 & 181 & 36 & 14.29 \\
\hline 11 & 70 & 10 & 8.54 \\
\hline 13 & 82 & 7 & 7.41 \\
\hline 15 & 27 & 2 & 0 \\
\hline 18 & 11 & 0 & 22.4 \\
\hline Total & 1000 & 224 & \\
\hline & & & \\
\hline
\end{tabular}


Table 4: Sex susceptibility of the examined camels to tick infestation.

\begin{tabular}{|c|c|c|c|}
\hline Sex & $\begin{array}{c}\text { Number of clinically } \\
\text { examined } \\
\text { animals }\end{array}$ & $\begin{array}{c}\text { Number of } \\
\text { infested } \\
\text { Animals }\end{array}$ & \% of infestation \\
\hline Male & 755 & 281 & $37.20 \%$ \\
\hline Female & 245 & 109 & $44.50 \%$ \\
\hline Total & 1000 & 390 & 39 \\
\hline
\end{tabular}

Table 5: Season influence on prevalence of ticks

\begin{tabular}{|c|c|c|c|}
\hline Season & $\begin{array}{c}\text { Number of } \\
\text { clinically examined } \\
\text { animals }\end{array}$ & $\begin{array}{c}\text { Number of } \\
\text { infested } \\
\text { animals }\end{array}$ & \%of infestation \\
\hline Hot months & 650 & 288 & 44.3 \\
\hline Cold months & 350 & 102 & 29.1 \\
\hline Total & 1000 & 390 & 39 \\
\hline
\end{tabular}

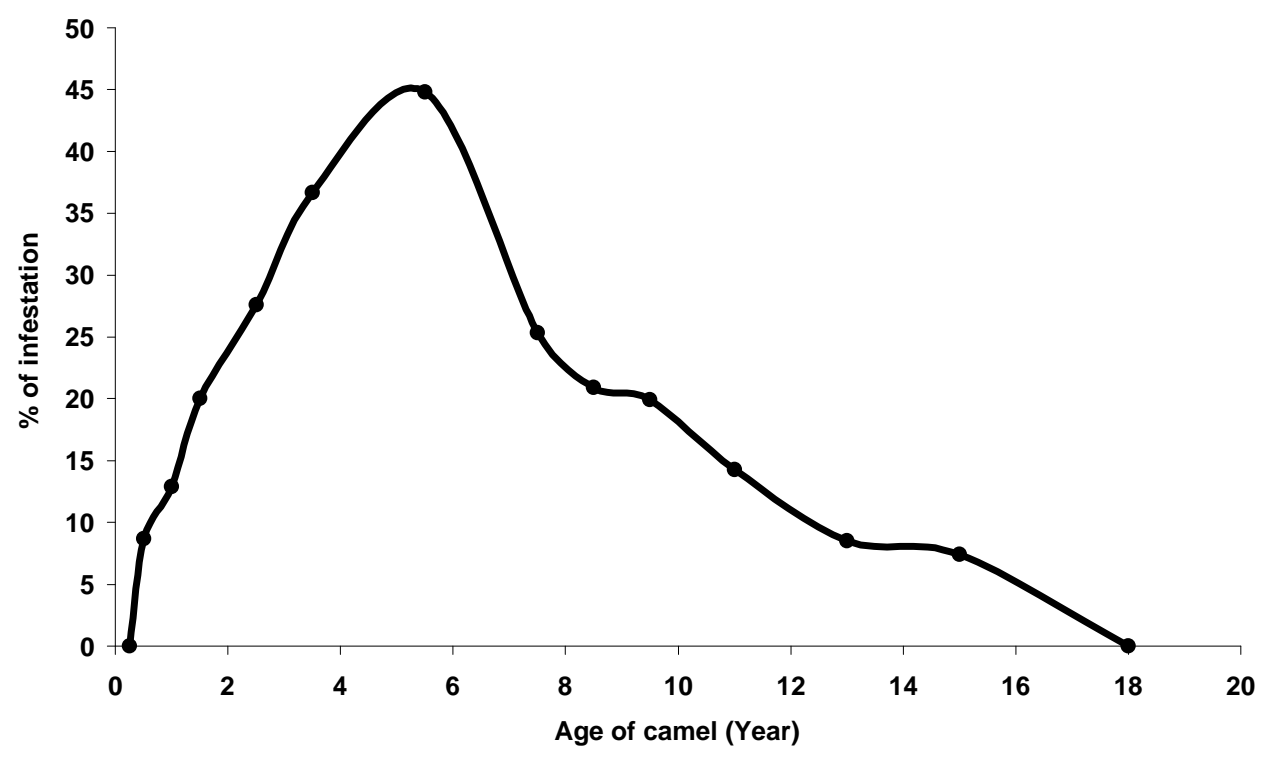

Fig. 1: Age susceptibility of tick infested camels. 


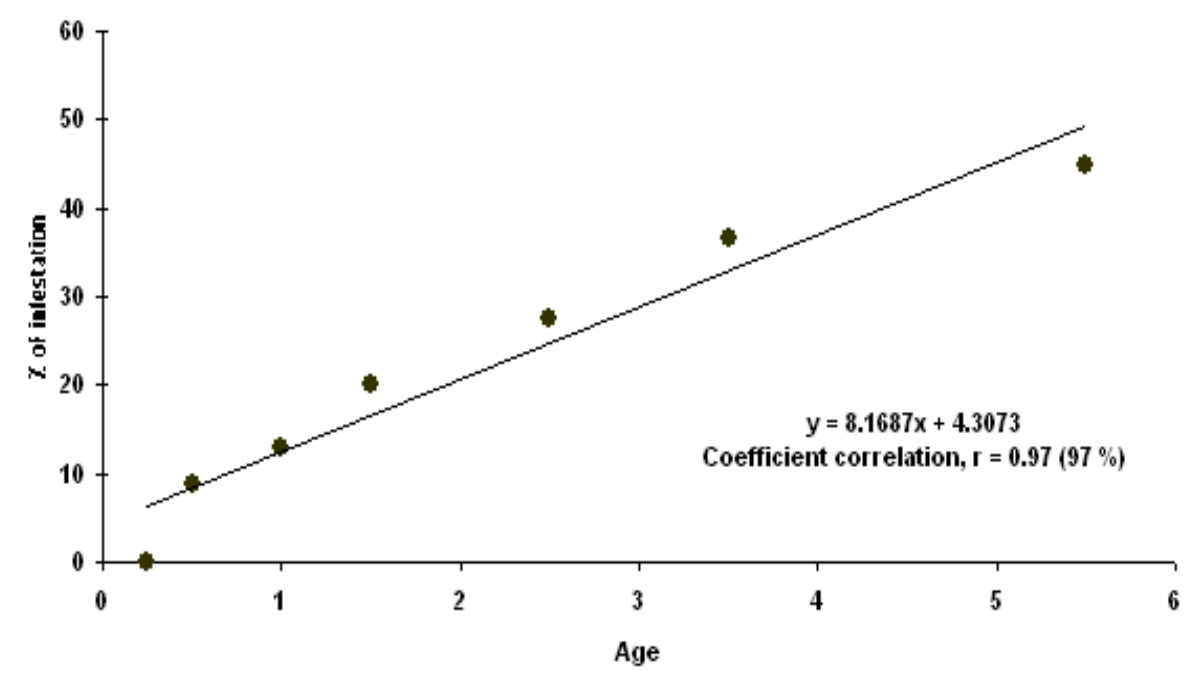

Fig. 2: Linear regression of age (set I from 0.25 to 5.5 years) of the examined camels upon the tick infestation rate $(\%)$.

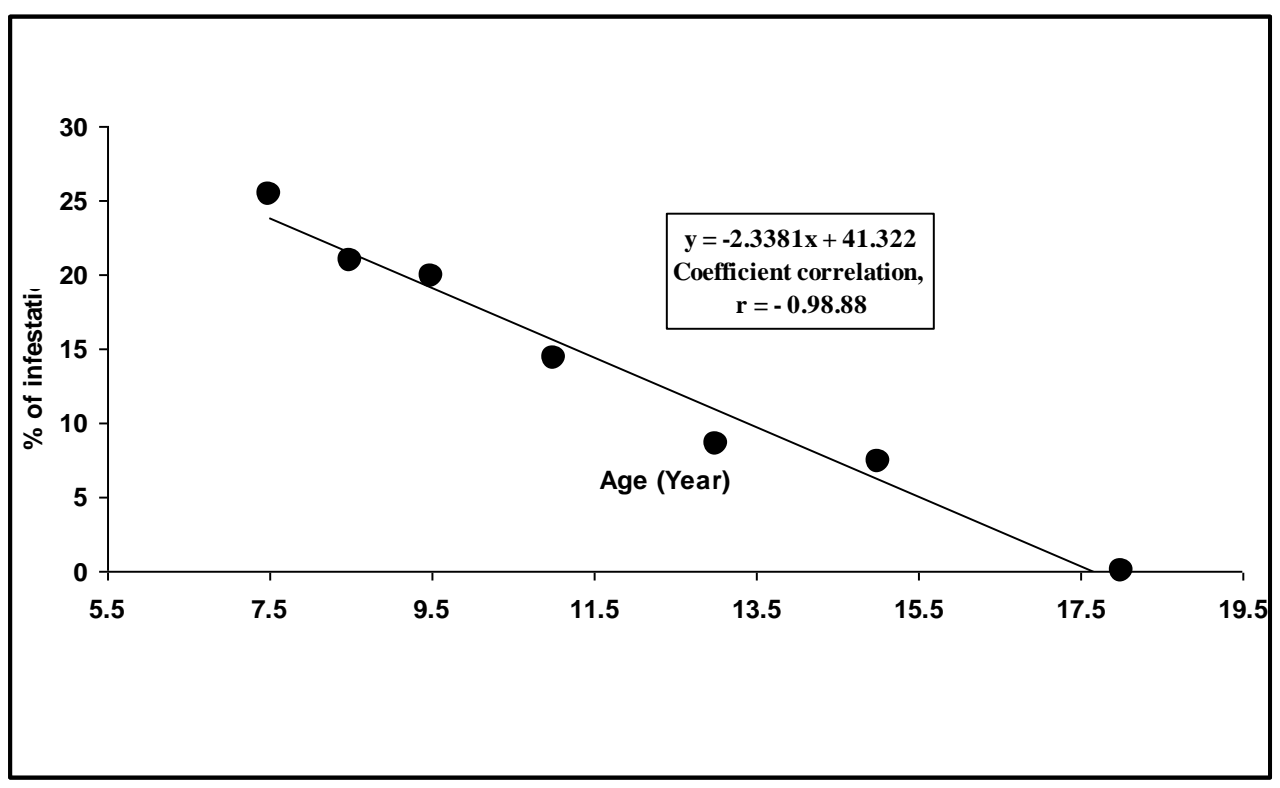

Fig. 3: Linear regression of age (set II from 7.5 to 18 years) of the examined camels upon the tick infestation rate $(\%)$. 


\section{DISCUSSION}

The present work elucidated that overall prevalence of tick infestation of the examined camels in different localities of Upper Egypt was 39\%. This result was coincided with that reported by Mahran and Saleh (2004). They found that $30.14 \%$ of the examined camels at Shalatin, Red Sea Governorate, Egypt, were infested by ticks. Higher percentages of tick infestation in camels under Egyptian field conditions were previously reported by Abdel-Gawad (1979) and Amin et al. (2006). They indicated that the percentages of tick infestation were $82.6 \%$ and $48.65 \%$ respectively. Conversely Hamed (2005) and El-Badr et al. (2007) indicated that the prevalence rate of tick infestation in camels was $5.89 \%$ in Upper Egypt and 25\% in Sohage Governorate respectively. These differences in tick prevalence may be attributed to size of camel population, climatological and ecological features of various localities.

From an epizootiological point of view, the current study indicated that there was a highly significant increase $(\mathrm{p}<0.01)$ in prevalence rate of tick infestation in camels located in El-Wady El-Gadid Governorate. This may ascribe to the desert nature of El-Wady El-Gadid Governorate that has characteristic climatological features. Moreover, Hyalomma species the predominant found tick of camels prefers low humidity and high temperature as in desert areas (Abd-El-Magied and Abou-Zeid, 1983 and Higgins, 1986). The presence of large number of camels in this area, maintained by the camelmen for long periods, allows easily spreading of ticks. Field observation revealed that camels are kept at night in narrow room with unhygienic measures. These rooms full of cracks where ticks can live, moult and lay eggs, also the narrow place facilitate the transmission of ticks from one animal to another and presence of ticks in the place grantee the continuous reinfestation even with repeated spraying of camels or treatment with acricides. Tick infestation and all Acaridae are adaptational diseases synchronized with the unclean surrounding environment Zaitoun (2007).

Concerning age susceptibility of camels to tick infestation, the present work revealed that the prevalence rate of tick infestation was gradually increased by increasing the age of animal (strong positive correlation, correlation coefficient $\mathrm{r}=0.97 \%$ ) and the peak of infestation $(44.78 \%)$ was found at 5.5 years $(\mathrm{p}<0.01)$. Thereafter, the prevalence of tick infestation was decreased by increasing the age of infested camel (strong negative correlation, correlation coefficient $r=-98.88$ ) till reach $7.41 \%$ at 15 years. Camels with 18 years or more were found tick free. Low prevalence of tick infestation in aged camels may refer to a build-up 
of acquired immunological status. Haematophagous arthropods including ticks of family Ixodidae stimulate immune defense mechanisms of the infested host that react with tissue and saliva of the parasites. This may hinder blood meal acquisition, or probably kill the arthropod (Wikel, 1982 and Wikel, 1996). Furthermore, the increasing in the thickness of the skin in aged animals may also play a pivotal role in resistance of external parasites infestation. On the other hand, the low percent of infestation with ticks in the neonates and young animals may ascribe to the greater attention of camelmen to young age animals than adults or probably due to maternal immunity, which originate from dams previously exposed to tick infestation (Zaitoun (2007). However such probable reason in need of further investigation.

Under field conditions, the peak of tick infestation was found in camels 5-7 years of age, and this may be associated with the fact that adult camels are periodically used as work animals and they are more frequently exposed to different degrees of the skin affections and external parasitic infestation Hamed (2005). El-Badr et al. (2007) found that the prevalence rate of tick infestation was higher in camels more than 5 years of age than camels less than 5 years of age. This may give account to peak of tick infestation in camels of 5-7 years of age.

Sex variance of camels and prevalence rate of tick infestation was also epizootiologically monitored. The susceptibility rate of females $(44.5 \%)$ to tick infestation was highly significant $(\mathrm{p}<0.01)$ in contrast to males $(37.20 \%)$. Such difference is not related to sex, but may attributed to the fact that owners always keep females for long period for breeding but males used for a short period for work and then slaughtered as meat producing animal and consequently the spreading and persistence of ticks takes its chance more frequently in the female camels. In the present work, the prevalence rate of tick infestation reached to a highest value at ElWady El-Gadid Governorate, where camelmen keep female camels for breeding for long periods. El-Badr et al. (2007) also found that the percent of infection is higher in she camels than males.

Seasonal influence on the prevalence of ticks in camels was studied and indicated that the percentage of infestation with ticks reached its peak $(\mathrm{p}<0.01)$ at hot months of the year $(44.3 \%)$. Dioli and Stimmelmayr (1992) and Rollefson et al. (2001) declared that ticks were adapted to warm climate and their process of development is greatly influenced by ambient temperature, and during the warm climate, crowding of camels at watering points facilitate spread and increase infestation rate. Similar results were previously reported by Mahran and Saleh (2004), Hamed (2005) and Amin et al. (2006). 


\section{REFERENCES}

Abdel-Gawad, A.M.H. (1979): Some morphological-biological studies on camelian ticks under the Egyptian environmental conditions. PhD. Thesis. Department of Parasitology. Faculty of Veterinary Medicine-Cairo University.

Abd El-Magied, S. and Abou-Zeid, I.M. (1983): Domestic animals infested by hard ticks in Dakahlia, Egypt. Journal of the Egyptian Society of Parasitology, 13 (1): 135-138.

Amin, M.M.; Youssef, R.R.; El-Naggar, A.L.; Mohmoud, M.A. and ELKattan, A. (2006): Some studies on skin affections among local and imported camels in Halaieb, Shalateen and Abou-Ramad areas. Vet.Med.J.Giza. 54 (3): 691-700.

Chatfield, C. (1970): Statistics for Techology. $1^{\text {st }}$ Ed. Penguin Books Baltimore, Maryland.

Dioli, M. and Stimmelmayr, R. (1992): Important Camel Diseases. In: The One-Humped Camel in Eastern Africa. A pictorial guide to diseases, health care and management. Edited by Schwartz, H.J. and Dioli, M., Verlag Josef margrave, Scientific Books.

Dolan, R.; Wilson, A.J.; Schwartz, H.J.; Newson, R.M. and Field, C.R. (1983): Camel production in Kenya and its constraints. II. Tick infestation. Trop. Anim. Hlth. Prod. 15: 179-185.

El-Badr, A.M.; Abdel-Salam, F.A.; Zaghlol, D.A.M. and Abdu, A. (2007): Ectoparasites of camels in Sohag governorate with special reference to those transmissible to man. EVMSPJ. IV(1): 878-888.

El-Kady, G.A. (1998): Protozoal parasites in tick species infesting camels in Sini Peninsula. Journal of the Egyptian Society of Parasitology, 28 (3): 765-776.

Hamed, M.I. (2005): Epidemiological studies on infectious skin affections of camels (Camelus dromedarius) in Upper Egypt. M.V.Sc. Thesis. Dept. of Animal Medicine (Infectious diseases), Faculty of Veterinary Medicine, Assiut University, Egypt.

Higgins, A.J. (1986): The camel in health and disease. $1^{\text {st }}$ Edition. London, Bailliere Tindall.

Rollefson, Paul Mundy and Evelyn Mathias (2001): Skin Problems. In A Field Manual of Camel Diseases. Traditional and modern health care for the dromedary. ITDG Publishing, 69-98. 
Mahran, O.M. and Saleh, M.A. (2004): Prevalence of ectoparasites and their effect on some biochemical indices in camels (Camelus dromedarius) at Shalatin City. Assiut Vet. Med. J., 50 (100): 164-187.

Milton, J.S. and Tsokos, J.O. (1983): Statistical methods in biological and health science. International Student Edition. McGraw-Hill International Book Co.

Steward, J.S. (1950): Notes on Some Parasites of Camels (Camelus dromedaries) in the Sudan. Veterinary Record. 62(52): 835-837.

Wikel, S.K. (1982): Immune responses to arthropods and their products. Ann. Rev. Entomol. 27: 21-48.

Wikel, S.K. (1996): Host immunity to ticks. Ann. Rev. Entomol. 41: 1-21.

Zaitoun, A.M.A. (2007): Contagious Skin Necrosis of Dromedary Camels in South Egypt. Journal of Camel Practice and Research. 14 (2): 125-132. 